\title{
METODE AUDIOLINGUAL DALAM PEMBELAJARAN BAHASA ARAB UNTUK MENINGKATKAN KEMAMPUAN BERBICARA
}

\author{
Maspalah \\ SMAN 1 Cicurug Sukabumi \\ Korespondensi: Jl. Koramil Cicurug Kabupaten Sukabumi 43259 \\ Pos-el: maspalah@gmail.com
}

\begin{abstract}
Abstrak
Penelitian ini bertujuan untuk mengkaji pengaruh penggunaan metode audiolingual dalam pembelajaran bahasa Arab terhadap peningkatan kemampuan berbicara siswa. Metode yang digunakan adalah Penelitian Tindakan Kelas yang dilaksanakan dalam dua siklus dengan subjek penelitian siswa Kelas XI MIA-2 SMAN 1 Cicurug Kabupaten Sukabumi Tahun 2014. Hasil penelitian menunjukkan bahwa penggunaan metode audiolingual dalam pembelajaran bahasa Arab dapat meningkatkan kualitas proses dan hasil belajar siswa. Kualitas proses dapat dilihat dari peningkatan keterlibatan siswa dalam pembelajaran, sedangkan kualitas hasil terlihat dari peningkatan nilai hasil belajar yang menunjukkan kemampuan berbicara siswa pada Siklus I sebesar 80,96 dan Siklus II sebesar 83,59. Adapun persentase keterlibatan siswa dalam belajar pada Siklus 1 sebesar 86,8\% dan pada Siklus 2 sebesar 92,1\%.
\end{abstract}

Kata-kata kunci: Metode audiolingual, pembelajaran bahasa Arab, kemampuan berbicara

\begin{abstract}
This study aims to determine the effect of the use of methods audiolingual in Arabic learning to increase their speaking ability. The method used is a Class Action Research conducted in two cycles with a Class XI Science 2 SMAN 1 Cicurug Sukabumi 2014. The results showed that the use of methods audiolingual in Arabic learning can improve the quality of student learning processes and outcomes. The quality of the process can be seen from the increase in student engagement in learning, while the quality of the results, the increase in the value of learning outcomes that demonstrate the ability to speak the students in the first cycle was 80.96 and 83.59 for Cycle II. The percentage of student engagement in learning in Cycle 1 at $86.8 \%$ and in Cycle 2 of $92.1 \%$.
\end{abstract}

Keywords: Audio lingual methods, learning Arabic, speaking ability

\section{PENDAHULUAN}

Bahasa Arab adalah salah satu mata pelajaran bahasa asing pilihan yang diajarkan di SMA. Salah satu keterampilan berbahasa yang harus dikuasai oleh siswa adalah kemampuan berbicara atau kemampuan menyusun teks lisan sebagaimana ditegaskan dalam Lampiran I Permendikbud Nomor 59
Tahun 2014 tentang Kompetensi Dasar Mata pelajaran Bahasa Arab SMA.

Kemampuan menyusun teks lisan ditandai dengan kemampuan untuk mengungkapkan maksud, gagasan, dan pikirannya dalam bahasa target meskipun secara sederhana. Untuk mencapai sasaran tersebut, diperlukan kemampuankemampuan untuk membekali siswa menuju kemampuan komunikatif yang sebenarnya. Salah satu kemampuan dasar 
yang harus dikuasai siswa adalah kemampuan untuk mempraktikkan model dialog dengan baik ditinjau dari ketepatan pelafalan huruf, ketepatan pelafalan vokal pendek/panjang, ketepatan intonasi, dan kelancarannya. Penguasaan model dialog merupakan modal dasar yang harus dikuasai oleh siswa sebelum masuk pada tahap penguasaan dialog bebas atau dialog kreatif.

Namun demikian, berdasarkan pengamatan peneliti di lapangan, banyak siswa, yang masih mengalami kesulitan dalam belajar berbicara, khususnya dalam mempraktikkan model dialog.

Hal ini terlihat dari hasil evaluasi kegiatan di akhir pembelajaran yang menunjukkan masih belum optimalnya hasil pembelajaran ini. Dari beberapa siswa yang dipilih secara acak untuk mempraktikkan dialog di depan kelas, umumnya penguasaan mereka masih kurang. Di samping pelafalan huruf, vokal, dan intonasinya masih banyak yang kurang tepat, juga masih banyak yang kurang lancar dalam menyampaikannya karena kesulitan menghafal. Mereka sangat bergantung pada tulisan pada buku catatannya.

Kurangnya kemampuan siswa dalam mempraktikkan model dialog ini kemungkinan dipengaruhi oleh berbagai faktor, antara lain karena kurang tepatnya langkah-langkah kegiatan pembelajaran yang digunakan. Dengan kata lain metode yang digunakan guru untuk mengajar berbicara masih belum tepat.

Penggunaan metode yang tepat merupakan salah satu penentu keberhasilan pembelajaran bahasa. Hal ini sejalan dengan pendapat Tim Pengembang Ilmu Pendidikan FIP UPI (tt:125) yang menyatakan bahwa pembelajaran bahasa dapat berjalan dengan lancar dan berhasil dengan baik, apabila metode yang digunakan sesuai dengan karakteristik materi yang akan diberikan pada peserta didik.
Salah satu metode mengajar yang telah banyak dilaporkan efektif untuk membantu siswa meningkatkan kemampuan berbicara dalam bahasa asing adalah metode audiolingual. Metode ini menurut Effendy (2009:57) berasal dari model pengajaran bahasa asing Army Specialized Training Program (ASTP) yang dibentuk oleh Departemen Pertahanan Amerika Serikat pada tahun empat puluhan, saat Amerika memerlukan personalian yang lancar berbahasa asing untuk ditempatkan di beberapa negara. Pengajaran bahasa asing model ASTP yang bersifat intensif dan berbasis penyajian lisan ini dianggap berhasil.

Meskipun metode ini dianggap berhasil membantu siswa dalam belajar berbicara bahasa asing, namun belum diperoleh data yang meyakinkan tentang pengaruhnya dalam peningkatan kemampuan berbicara dalam pembelajaran bahasa Arab karena belum dilakukan penelitian sebelumnya di tempat peneliti. Untuk itu penelitian ini bertujuan untuk mengisi kekosongan penelitian mengenai penerapan metode audiolingual dalam pembelajaran bahasa Arab di dalam kelas dan melihat pengaruhnya terhadap peningkatan kemampuan berbicara siswa secara sederhan, khususnya dalam mempraktikkan model dialog.

Metode

audio-lingual sebagaimana pada awalnya adalah sebuah metode yang digunakan pada kalangan militer di Amerika Serikat yang dikenal dengan army method. Metode ini menekankan pengajaran bahasa lewat mendengar dan menirukan, juga memungkinkan penggunaan bahasa ibu untuk penjelasannya (http://aginista.blogspot.com/2013/01/me tode-pembelajaran_20.html).

Metode audiolingual didasarkan atas beberapa asumsi. Di antara asumsi yang mendasari metode ini adalah bahwa bahasa itu pertama-tama adalah ujaran 
(Effendy, 2009:58). Oleh karena itu pengajaran bahasa harus dimulai dengan memperdengarkan bunyi-bunyi bahasa dalam bentuk kata atau kalimat kemudian mengucapkannya sebelum pelajaran membaca dan menulis.

Asumsi lain dari metode ini ialah bahwa bahasa adalah kebiasaan. Suatu perilaku akan menjadi kebiasaan apabila diulang berkali-kali. Oleh karena itu, pengajaran bahasa harus dilakukan dengan teknik pengulangan.

Metode audiolingual memiliki ciri-ciri yang khas dibandingkan dengan metode lain. Di antara ciri khas metode ini adalah dilakukannya banyak role-play atau dialog situasional (Tim Pengembang Ilmu Pendidikan FIP UPI, tt:126). Sedangkan Effendy (2009:59) menjelaskan karakteristik metode audiolingual ini, di antaranya adalah sebagai berikut:

1) Model kalimat bahasa asing diberikan dalam bentuk percakapan untuk dihafalkan.

2) Pengajaran sistem bunyi dilakukan secara sistematis agar dapat digunakan oleh pelajar dengan teknik demonstrasi, peniruan, komparasi, kontras, dan lain-lain.

3) Penggunaan bahan rekaman, laboratorium bahasa, dan visual aids sangat dipentingkan

Sebelum pelaksanaan penyajian metode audiolingual dalam pembelajaran, peneliti melakukan perencanaan meliputi pemilihan kosakata, pola kalimat, dan model dialog yang akan dilatihkan. Langkah selanjutnya adalah pelaksanaan dan penilaian. Kegiatan penilaian dilakukan di awal dan di akhir penyajian untuk melihat perubahan kemampuan berbicara siswa, khususnya dalam mempraktikkan model dialog.

Metode audiolingual memiliki kekuatan dan kelemahan. Di antara kekuatan metode ini seperti diungkapkan oleh Effendy (2009:60) adalah sebagai berikut:

1) Para pelajar memiliki keterampilan pelafalan yang bagus.

2) Para pelajar terampil membuat polapola kalimat baku yang sudah dilatihkan.

3) Pelajar dapat melakukan komunikasi lisan dengan baik karena latihan menyimak dan berbicara yang intensif.

4) Suasana kelas menjadi hidup karena para pelajar tidak tinggal diam tetapi terus-menerus merespon stimulus guru.

Adapun di antara kelemahan metode audiolingual adalah sebagai berikut:

1) Pelajar bisa berkomunikasi dengan lancar hanya apabila kalimat yang telah digunakan telah dilatihkan sebelumnya di dalam kelas.

2) Keaktifan siswa di dalam kelas adalah keaktifan yang semu karena mereka hanya merespon rangsangan guru. Semua bentuk latihan, materi pelajaran, sampai model pertanyaan dan jawaban, ditentukan oleh guru. Tidak ada inisiatif dan kreativitas dari siswa.

3) Latihan-latihan pola bersifat manipulatif, tidak kontekstual dan tidak realistis. Pelajar mengalami kesulitan ketika menerapkannya dalam konteks komunikatif yang sebenarnya.

\section{METODE}

Penelitian ini berpijak pada Penelitian Tindakan Kelas (PTK). Wardani dalam Sanjaya (2011:142) mendefinisikan PTK sebagai penelitan berupa proses pengkajian masalah pembelajaran di dalam kelas yang dirancang oleh guru di dalam kelasnya sendiri melalui refleksi diri dengan cara melakukan berbagai tindakan yang terencana dalam situasi nyata serta 
menganalisis setiap pengaruh dari perlakuan tersebut. Ditinjau dari jenisnya, penelitian ini termasuk PTK partisipan. Menurut Iskandar (2012:27) dalam PTK jenis partisipan, sejak perencanaan peneliti senantiasa terlibat, selanjutnya peneliti memantau, mencatat, dan mengumpulkan data, lalu menganalisa data serta berakhir dengan melaporkan hasil penelitiannya.

Tindakan yang dilakukan dalam penelitian meliputi kegiatan diagnostik dan teurapeutik (Emilia, 2013:38). Tindakan diagnostik dalam penelitian ini dilakukan sebelum Siklus 1, dimulai dengan melakukan pretes berupa tes praktik untuk mengidentifikasi kemampuan siswa dalam pelafalan huruf, vokal, intonasi, dan kelancaran mempraktikkan model dialog. Tindakan ini ini menggiring peneliti untuk melakukan refleksi awal dan studi pendahuluan untuk dapat menyusun perencanaan tindakan.

Setelah melakukan tindakan diagnostik, selanjutnya peneliti menentukan tindakan teurapeutik dengan menerapkan metode audiolingual. Tindakan ini dibagi dalam dua siklus dan tiap-tiap siklus terdiri atas empat tahap yakni perencanaan, pelaksanaan, observasi, dan refleksi. Hasil refleksi Siklus 1 merupakan bahan untuk menentukan perencanaan Siklus 2 .

\section{HASIL DAN PEMBAHASAN}

Penelitian ini dilakukan di Kelas XI MIA-2 SMAN 1 Cicurug Kabupaten Sukabumi Provinsi Jawa Barat yang dimulai ketika subjek penelitin masih berada di kelas $\mathrm{X}$ pada akhir semester genap tahun pelajaran sebelumnya. Kelas ini berjumlah 38 orang siswa yang terdiri atas 13 orang siswa laki-laki dan 25 orang siswa perempuan.

Berdasarkan hasil refleksi awal dan studi pendahuluan sebelum penggunaan metode audiolingual, peneliti menemukan fenomena beberapa orang siswa yang kesulitan dalam belajar bahasa Arab menunjukkan sikap yang anti pati dengan cara sibuk mengobrol dengan teman sebangkunya untuk memancing perhatian guru. Di sisi lain, ada juga siswa yang kemampuannya sangat menonjol.

Namun, secara keseluruhan siswa kelas ini belum menunjukkan kemampuan praktik berbicara bahasa Arab yang baik. Selain sulit menghafal contoh ungkapan-ungkapan bahasa Arab dan kurang lancar dalam mempraktikkan model dialog yang diberikan, intonasi dan ketepatan pengucapan vokal dan konsonan pun belum baik.

Pada tahap awal ini peneliti mengambil data kemapuan subjek penelitian dalam hal pelafalan huruf, pelafalan vokal pendek/panjang, intonasi, dan kelancaran penyampaian model dialog. Dari 38 orang siswa, ada 3 orang yang sudah menunjukkan kategori sangat baik, 4 orang baik, 21 orang masuk dalam kategori cukup, dan sisanya sebanyak 10 orang kemampuannya masih kurang.

Secara umum, tahapan penelitian ini terdiri atas:

1. Perencanaan, meliputi penyiapan RPP, alat observasi, bahan ajar, media pembelajaran, dan alat evaluasi untuk kemampuan memahami dan menyusun teks lisan sederhana tentang cara meminta perhatian dan memuji terkait topik keluarga (الأسرة) dengan materi contoh percakapan "أسرة علي" dan "أسرة محمب".

2. Tindakan, meliputi seluruh proses pembelajaran yang di dalamnya terdapat penggunaan metode audiolingual.

3. Observasi, dilaksanakan bersamaan dengan proses pembelajaran meliputi: aktivitas guru dan siswa, sikap siswa, dan hasil belajar siswa.

4. Refleksi, dilakukan dengan menganalisa kegiatan pembelajaran dan dilanjutkan dengan menyusun 
rencana perbaikan pada siklus berikutnya.

\section{A. Siklus 1}

Peneliti melaksanakan pembelajaran dengan membawa speaker aktif ke dalam kelas karena di sekolah

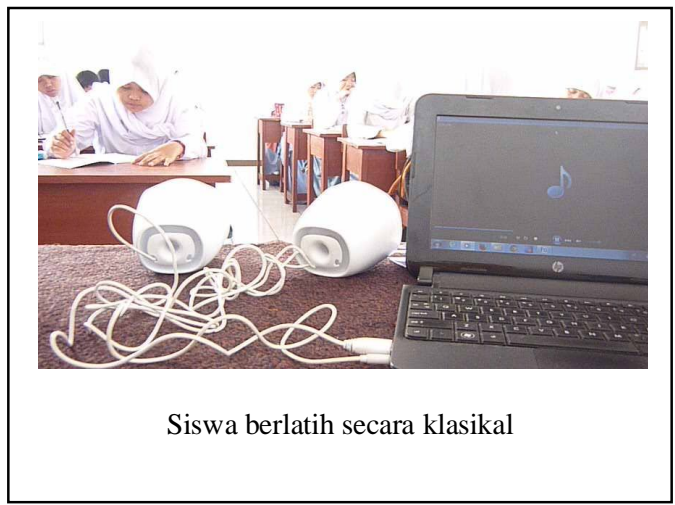

Data yang dihasilkan adalah nilai kemampuan mempraktikkan model dialog dengan memerankan tokoh dalam dialog tersebut. Mengingat jumlah jam pelajaran lintas minat di Kelas XI hanya 2 jam pelajaran, tidak semua siswa dapat menampilkan kemampuannya di depan kelas pada hari tersebut.

$$
\text { Meskipun kemampuan }
$$
mempraktikkan model dialog merupakan salah satu indikator kemampuan berbicara, pada siklus berikutnya peneliti peneliti belum ada laboratorium bahasa Meskipun suara penutur asli dalam rekaman masih harus disambung dengan suara guru, siswa cukup antusias mendengarkan, menirukan, dan melakukan latihan-latihan seperti tampak pada foto berikut.

Tabel 1. Tahapan kegiatan siklus 1

\begin{tabular}{|c|l|c|c|c|}
\hline No. & PERENCANAAN & TINDAKAN & OBSERVASI & REFLEKSI \\
\hline 1. & $\bullet$ Menyusun RPP & $\bullet$ Menyajikan materi & $\bullet$ Mengamati & $\bullet$ Mencatat hasil \\
& $\bullet$ Menyiapkan Media & pembelajaran & aktivitas siswa & observasi \\
& $\bullet$ Menyiapkan Alat & $\bullet$ Melakukan latihan & dan mencatat & $\bullet$ Mengevaluasi \\
& Observasi & dengar ucap secara & aktivitas guru & hasil observasi \\
& $\bullet$ Menyiapkan Alat & klasikal & $\bullet$ Mengamati & $\bullet$ Menganalisis \\
& Evaluasi & $\bullet$ Melakukan latihan & sikap siswa & hasil \\
& & dalam kelompok & terhadap & pembelajaran \\
& & $\bullet$ Melakukan latihan & metode yang & $\bullet$ Memperbaiki \\
& & dilaksanakan & kelemahan \\
& & $\bullet$ Melaksanakan tes & $\bullet$ Mengamati & untuk siklus \\
& & praktik & berikutnya \\
& & individual & siswa \\
& & &
\end{tabular}


Pembelajaran pada pertemuan pertama Siklus 1 merupakan perbaikan dari hasil refleksi terhadap proses pembelajaran sehari-hari setelah diketahui kemampuan berbicara mereka dalam hal mempraktikkan model dialog belum optimal. Pertemuan pertama Siklus 1 ini terdiri atas dua pertemuan yang dilaksanakan pada hari Senin, 11 Agustus 2014 sebagai pertemuan pertama dan pada hari Senin, 25 Agustus 2014 sebagai pertemuan kedua. Kemampuan yang ditonjolkan adalah mempraktikkan model teks dialog bahasa Arab dengan topik keluarga (الأسرة) dengan baik. Target yang dijadikan patokan adalah peningkatan nilai ratarata kelas dan persentase jumlah siswa yang berkategori di atas cukup (Baik dan Sangat Baik) mencapai $75 \%$.

Setelah latihan dengar ucap berdasarkan metode audiolingual ini dilaksanakan, peneliti malakukan penilaian kemampuan siswa dengan tes lisan dan tes praktik. Soal tes lisan ditujukan kepada seluruh kelas secara umum, sedangkan tes praktik diamati secara individual dalam dialog secara berpasangan.

Unsur yang dinilai terdiri atas 4 aspek yakni (1) ketepatan pengucapan huruf, (2) ketepatan pengucapan vokal pendek dan panjang, (3) ketepatan intonasi, dan (4) kelancaran. Skor untuk tiap aspek antara 1 sampai dengan 4 . Skor 1 diberikan apabila masuk kategori kurang karena sangat banyak kesalahan, skor 2 diberikan apabila masuk kategori cukup karena ditemukan ada beberapa kesalahan, skor 3 diberikan apabila masuk kategori bagus tetapi masih ada sedikit kesalahan, dan skor 4 diberikan apabila masuk kategori sangat bagus sehingga hampir tidak tampak adanya kesalahan. Jumlah aspek adalah 4 dengan skor maksimal tiap aspek 4, jadi total skor maksimal adalah 16.

Daftar cek dan rincian aspek yang dinilai tersebut tampak pada tabel 2 di bawah

Tabel 2. Daftar cek dan rincian aspek yang dinilai

\begin{tabular}{|c|l|c|c|c|c|}
\hline \multirow{2}{*}{ No } & \multicolumn{1}{|c|}{ ASPEK } & \multicolumn{3}{|c|}{ Skor (1-4) } \\
\cline { 3 - 6 } & \multicolumn{1}{|c|}{} & 1 & 2 & 3 & 4 \\
\hline 1 & Ketepatan pengucapan huruf & & & & \\
\hline 2 & Ketepatan pengucapan vokal pendek dan panjang & & & & \\
\hline 3 & Ketepatan intonasi & & & & \\
\hline 4 & Kelancaran TOTAL SKOR & & & & \\
\hline \multicolumn{2}{|c|}{} & \multicolumn{2}{|l}{} \\
\hline
\end{tabular}

Berdasarkan data hasil penelitian diketahui nilai terendah adalah 69 , nilai tertinggi 90, dan nilai rata-rata sebesar 80,03. Di antara 38 orang siswa yang mengikuti tes praktik, ada 3 orang $(7,9 \%)$ yang termasuk kategori sangat baik, 12 orang $(31,6 \%)$ berkategori baik, 17 orang $(42,1 \%)$ termasuk kategori cukup, dan 7 orang $(18,4 \%)$ masih termasuk ke dalam kategori kurang. Apabila persentase jumlah siswa sesuai dengan kategori kemampuan berbicaranya pada pertemuan ke-1 Siklus I disajikan dalam Grafik batang, tampak seperti pada Grafik 1 di bawah ini. 


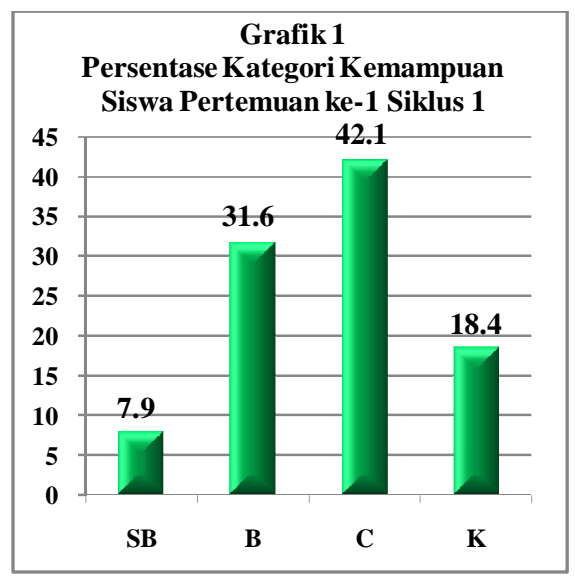

$\begin{array}{ll}\text { Adapun hasil pengamatan guru } & \text { berkategori baik, } 13 \text { orang }(34,2 \%) \\ \text { terhadap praktik berbicara pada } & \text { termasuk kategori cukup, dan 1 orang } \\ \text { pertemuan kedua Siklus I diketahui nilai } & (2,6 \%) \text { masih termasuk ke dalam } \\ \text { terendah adalah } 69 \text {, nilai tertinggi } 90 \text {, dan } & \text { kategori kurang. Persentase jumlah siswa } \\ \text { nilai rata-rata sebesar } 81,89 \text {. Di antara } 38 & \text { sesuai dengan kategori kemampuan } \\ \text { orang siswa yang mengikuti tes praktik, } & \text { berbicaranya pada pertemuan ke-2 Siklus } \\ \text { ada } 3 \text { orang }(7,9 \%) \text { yang termasuk } & \text { I, tampak seperti pada Grafik 2 di bawah } \\ \text { kategori sangat baik, 21 orang }(55,3 \%) & \text { ini. }\end{array}$

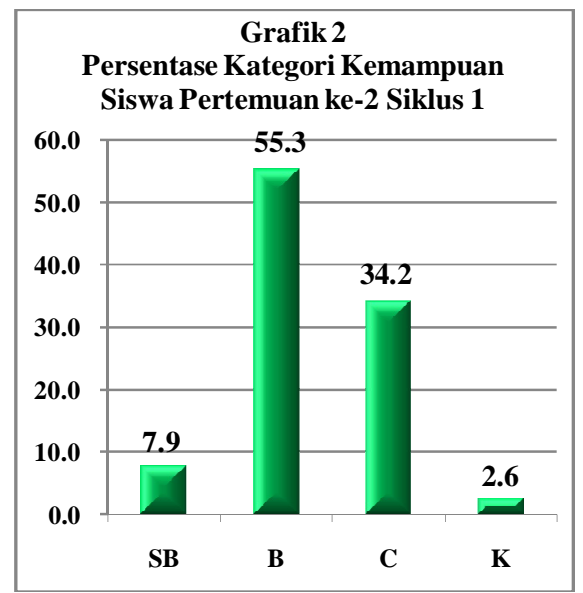

Setelah menggunakan metode audiolingual dalam pembelajaran yang dilakukan pada Siklus 1, peneliti kemudian melakukan refleksi mengenai perubahan yang terjadi pada siswa, suasana kelas, dan guru akibat tindakan tersebut.

Perubahan yang terjadi pada siswa adalah timbulnya semangat dan motivasi mereka dalam belajar karena mereka diberi tahu sejak awal bahwa akan ada penilaian antarpasangan dalam memerankan tokoh dalam dialog tanpa melihat teks dengan ekspresi yang wajar dan sesuai. Mereka lebih fokus dan serius dalam mengikuti presentasi materi oleh guru dan latihan.

Penggunaan metode audiolingual pada Siklus 1 cukup berhasil meningkatkan hasil belajar siswa meskipun dari dua pertemuan pada siklus 1 ini masih ada beberapa orang siswa yang belum menunjukkan hasil yang baik. 
Meskipun pelaksanaan metode ini cukup baik, pada Siklus 1 peneliti menemukan hal-hal yang perlu diperbaiki. Ada beberapa orang di antara mereka yang masih belum terlibat secara penuh ketika berlatih dalam kelompoknya. Di antara mereka juga tampak kebosanan dengan terus mengucap ulang bahkan ada yang kurang perhatian dan mencari kesibukan sendiri. Meskipun ada beberapa pasangan yang berani tampil di depan, mereka belum tampak tertarik memperhatikan. Padahal dengan memperhatikan penampilan siswa lain, mereka akan mendapatkan penguatan ingatan dan pemahaman.

Kurangnya perhatian kelompok terhadap penampilan pasangan lain saat berlatih ke depan disebabkan karena yang tampil ke depan lebih mengutamakan hafal teks tanpa mempedulikan kewajaran dialog dan ekspresi. Oleh karena itu, pada siklus berikutnya, dalam latihan mereka akan diberi kebebasan untuk tampil semenarik mungkin dengan setting dan ekspresi menurut penghayatan masingmasing.Untuk membangkitkan semangat mereka dalam berlatih, pada siklus berikutnya mereka akan diberi tantangan untuk beradu kekompakan antarkelompok. Jika anggota kelompoknya tidak terlibat dalam megucapkan ungkapan sesuai dengan dialog, maka mereka akan mendapat pengurangan nilai.

\section{B. Siklus II}

Pembelajaran pada Siklus II merupakan perbaikan dari hasil refleksi terhadap proses pembelajaran pada Siklus I. Pembelajaran Siklus 2 ini dilaksanakan pada hari Senin, 8 September 2014 dan Senin, 22 September 2014 dengan materi contoh سعيد يعمل “ " dan "أسرة أحمد" percakapan الثشاي

Pada Siklus II ini suasana berbeda mulai dirasakan setelah guru menyampaikan bahwa dalam latihan mereka akan bertanding kekompakan kelompok dengan kelompok lain sesuai peran dalam teks dialog yang dilatihkan. Setelah itu akan dilanjutkan dengan mengambil salah seorang di antara kelompok dan akan berdialog dengan wakil dari kelompok lain. Mereka sangat antusias dalam berlatih agar penampilannya tidak mengecewakan kelompoknya. Suasana ramai pun lebih terasa terutama jika tampak jelas perbedaan antara yang lancar dan yang lupa teks. Kadang-kadang mereka tidak tahan untuk tertawa mendengar dan melihat wakil kelompok lain yang kurang lancar atau memberi semangat kepada teman sekelompoknya. Meskipun kadang-kadang kelas menjadi cukup ramai, mereka mendapat penguatan dari latihan ini.

Hasil penelitian pada Siklus II diketahui nilai terendah adalah 70 , nilai tertinggi 95, dan nilai rata-rata sebesar 82,53. Di antara 38 orang siswa yang mengikuti tes praktik, ada 6 orang $(15,8 \%)$ yang termasuk kategori sangat baik, 20 orang $(52,6 \%)$ berkategori baik, 12 orang $(31,6 \%)$ termasuk kategori cukup.

Persentase jumlah siswa sesuai
dengan kategori kemampuan
berbicaranya pada pertemuan ke-1 Siklus
II disajikan dalam Grafik 3 di bawah ini.




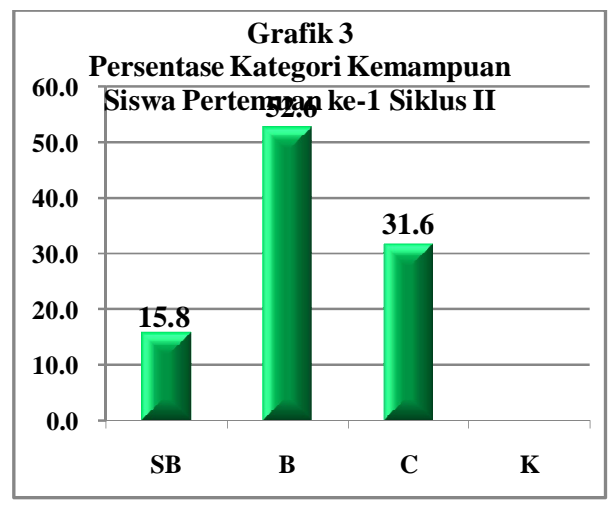

Siswa yang hasil tes praktik sebelumnya masih kurang, dipandu oleh temannya yang memiliki kemampuan cepat dalam menghafal dan memahami

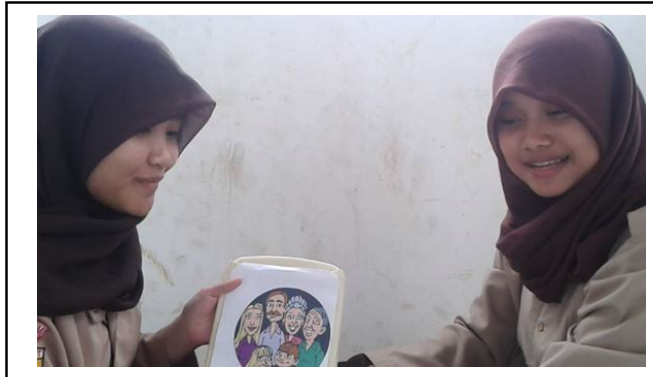

Siswa tampil dengan tenang dan ekspresif

Hasil penelitian pada pertemuan kedua Siklus II diketahui nilai terendah adalah 79 , nilai tertinggi 95 , dan nilai rata-rata sebesar 84,66. Dari 38 orang siswa yang mengikuti tes praktik, ada 8 serta fasih dalam pengucapan sehingga hal ini berpengaruh terhadap peningkatan kemampuan dan rasa percaya diri mereka seperti tampak pada foto berikut.

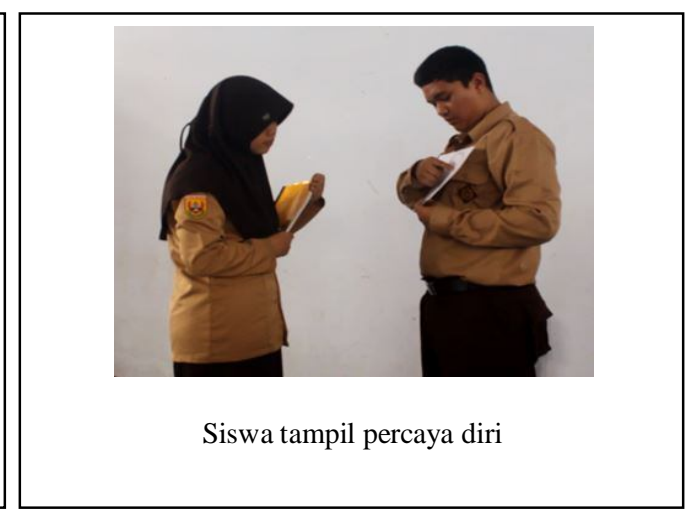

orang $(21,1 \%)$ yang termasuk kategori sangat baik, 26 orang $(68,4 \%)$ berkategori baik, dan 4 orang $(10,5 \%)$ termasuk kategori cukup. Hal ini tampak dalam Grafik 4 di bawah ini.

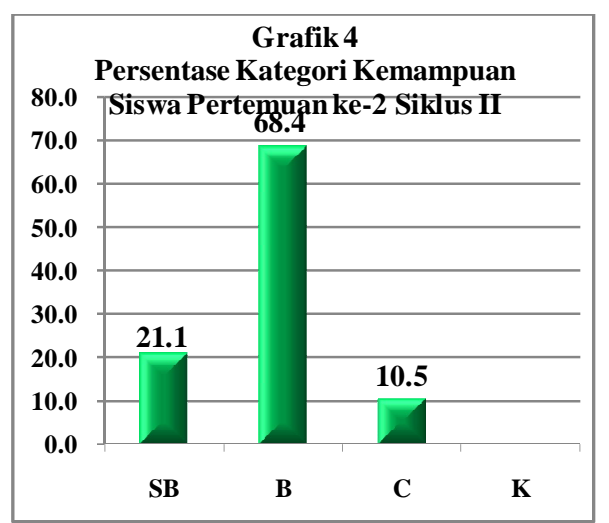


Setelah pelaksanaan dan observasi Siklus II dilalui, peneliti melakukan refleksi mengenai perubahan yang terjadi pada siswa, suasana kelas, dan guru akibat penggunaan metode audiolingual ini. Perubahan yang terjadi pada siswa adalah meningkatnya motivasi mereka dalam belajar terutama saat melakukan latihan.

Penggunaan metode audiolingual yang dimodifikasi dengan adanya pertandingan kelancaran dan kekompakan kelompok dalam membawakan dialog pada Siklus 2 cukup berhasil meningkatkan hasil belajar siswa. Perolehan rata-rata nilai di atas 80 dan persentase kategori di atas cukup yang melebihi $75 \%$ merupakan pencapaian yang membuktikan efektivitas pembelajaran. Dengan demikian Penelitian Tindakan Kelas ini tidak dilanjutkan pada Siklus 3 .
Data-data hasil penelitian kemudian dianalisis untuk melihat peningkatan hasil belajar dan peningkatan aktivitas siswa dalam pembelajaran Bahasa Arab dengan penggunaan metode audiolingual.

Pada pembelajaran Siklus 1, guru melaksanakan pembelajaran dengan metode audiolingual dengan hanya menggunakan teknik dengar ucap dan substitusi untuk menguasai kosa kata dan pola-pola ungkapan kalimat. Namun, karena sifat perulangan yang menimbulkan kebosanan, peneliti menemukan beberapa siswa yang mencuri-curi kesempatan untuk melakukan kegiatan sendiri seperti mengobrol ataupun tidak terlibat penuh dalam menirukan dan mengungkapkan kalimat-kalimat bahasa Arab yang dicontohkan. Hasil penelitian terlihat pada Tabel 3 di bawah ini:

Tabel 3. Ringkasan hasil penelitian siklus I

\begin{tabular}{|c|l|c|}
\hline No. & \multicolumn{1}{|c|}{ Hasil Penelitian } & Jumlah \\
\hline 1. & Nilai rata-rata pertemuan ke-1 dan ke-2 & 80,96 \\
\hline 2. & Persentase kategori di atas cukup (B dan SB) & $51,3 \%$ \\
\hline 3. & Persentase keterlibatan siswa dalam belajar & $86,8 \%$ \\
\hline
\end{tabular}

Interpretasi terhadap hasil penelitian di atas adalah bahwa pembelajaran masih perlu diperbaiki dan ditingkatkan. Kegiatan tanya jawab dengan guru sebelum pelaksanaan materi baru perlu dilakukan. Selain itu, jumlah anggota kelompok pun harus disederhanakan untuk meningkatkan keterlibatan siswa.

Pada pembelajaran Siklus II, guru sudah melaksanankan penggunaan metode audiolingual dan dimodifikasi dengan latihan pertandingan kekompakan antarkelompok. Sebelum pembelajaran dimulai dilakukan kegiatan tanya jawab secara klasikal antara siswa dengan guru. Jumlah anggota kelompok sudah disederhanakan sehingga aktivitas latihan dalam kelompok lebih mudah terkontrol. Hasil penelitian Siklus II yang merupakan rata-rata dari dua pertemuan dapat dilihat pada Tabel 4 di bawah ini.

Tabel 4. Ringkasan hasil penelitian siklus II

\begin{tabular}{|c|l|c|}
\hline No. & \multicolumn{1}{|c|}{ Hasil Penelitian } & Jumlah \\
\hline 1. & Nilai rata-rata pertemuan ke-1 dan ke-2 & 83,59 \\
\hline 2. & Persentase kategori di atas cukup (B dan SB) & $78,9 \%$ \\
\hline 3. & Persentase keterlibatan siswa dalam belajar & $92,1 \%$ \\
\hline
\end{tabular}


Hasil penelitian di atas dapat diinterpretasikan bahwa pada Siklus II pembelajaran sudah menunjukkan peningkatan hasil belajar dan peningkatan keterlibatan siswa dalam pembelajaran.

Data hasil tes pada Siklus 1 dan 2 adalah data yang digunakan untuk mengukur peningkatan kemampuan berbicara siswa melalui penggunaan metode audiolingual dalam pembelajaran bahasa Arab. Peningkatan nilai dan persentase keterlibatan siswa pada Siklus I dan Siklus II dapat dilihat pada tabel 5 berikut.

Tabel 5. Ringkasan hasil penelitian siklus I dan II

\begin{tabular}{|c|l|c|c|}
\hline \multirow{2}{*}{ No. } & \multicolumn{1}{|c|}{ Hasil Penelitian } & Siklus I & Siklus II \\
\cline { 3 - 4 } 1. & $\begin{array}{l}\text { Nilai rata-rata pertemuan ke-1 } \\
\text { dan ke-2 }\end{array}$ & 80,96 & 83,59 \\
\hline 2. & $\begin{array}{l}\text { Persentase keterlibatan siswa } \\
\text { dalam belajar }\end{array}$ & $86,8 \%$ & $92,1 \%$ \\
\hline
\end{tabular}

Dari tabel di atas dapat kita lihat adanya peningkatan nilai praktik berbicara yakni pada Siklus I 80,96 dan pada Siklus II 83,59. Demikian juga terjadi peningkatan keterlibatan siswa dalam belajar dari $86,8 \%$ atau sekitar 33 orang siswa dari 38 yang terlibat penuh saat pembelajaran menjadi $92,1 \%$ atau sekitar 36 orang dari 38 yang konsisten mengikuti kegiatan dengan keterlibatan dalam setiap latihan. Apabila disajikan dalam grafik, tampak dalam Grafik 5.

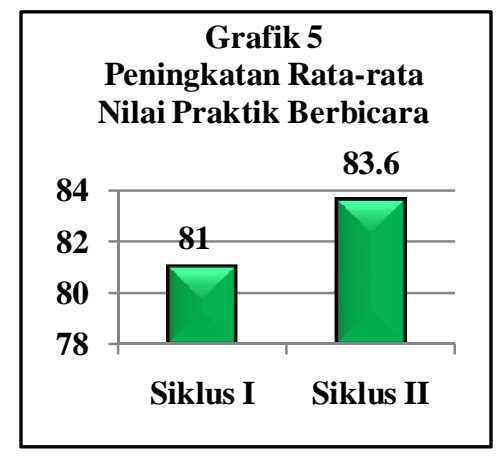

Keterlibatan siswa dalam pembelajaran dapat ditinjau dari banyaknya siswa yang terlibat aktif saat Kegiatan Inti dalam KBM. Hasil penelitian menunjukkan bahwa siswa yang tetap mengikuti kegiatan belajar dengan penuh perhatian pada Siklus I pertemuan ke-1 sebanyak 32 orang dan pertemuan ke- 2 sebanyak 34 orang dari total siswa kelas ini sebanyak 38 orang. Jika dirata-ratakan ada 33 orang atau
$86,8 \%$. Sedangkan pada Siklus II pertemuan 1 sebanyak 36 orang, demikian juga pada pertemuan ke-2 hanya ditemukan dua orang siswa yang seringkali mengganggu temannya. Artinya sekitar 92\% siswa mengikuti pembelajaran bahasa Arab dengan penuh perhatian. 


\section{SIMPULAN}

Dari penelitian tindakan kelas yang telah dilakukan, dapat disimpulkan bahwa kemampuan berbicara siswa sebagai hasil pembelajaran bahasa Arab dengan penggunaan metode audiolingual di Kelas XI MIA-2 menunjukkan adanya peningkatan, baik peningkatan Nilai Rata-rata maupun peningkatan persentase kategori kemampuan dan ketuntasan belajar. Demikian juga keterlibatan siswa dalam kegiatan pembelajaran bahasa Arab dengan penggunaan metode audiolingual ini cukup tinggi dan dapat ditingkatkan dengan mengondisikan mereka agar merasa tertantang dan terlibat penuh di dalamnya.

\section{UCAPAN TERIMA KASIH}

Peneliti mengucapkan terima kasih kepada semua pihak yang telah membantu penulisan artikel ini. Ucapan terima kasih juga disampaikan kepada Jurnal bahasa \& sastra yang telah memublikasikan artikel ini.

\section{PUSTAKA RUJUKAN}

Depdikbud. (2014). Lampiran Permendikbud Nomor 59 Tahun 2014 tentang Kompetensi Dasar. Jakarta: Balitbang Puskur.

Effendy, A. (2009). Metodologi Pengajaran Bahasa Arab. Malang: Misykat.

Emilia, E. (2013). "Penelitian Tindakan Kelas". Materi Diklat Metodologi Penelitian dan Pengajaran Bahasa. Jakarta: SEAMEO Qitep in Language.

Iskandar, M. (2012). Penelitian Tindakan Kelas. Jakarta: Referensi.

Metode Audiolingual. (2013). Diunduh tanggal 24 Oktober 2013 dari: http://aginista.blogspot.com/2013/ 01/metodepembelajaran_20.html.

Sanjaya, W. (2011). Penelitian Tindakan Kelas. Jakarta: Kencana.

Tim Pengembang Ilmu Pendidikan FIP UPI. (tt). Ilmu \& Aplikasi Pendidikan Bagian III. Bandung: PT Imperial Bhakti Utama. 